\title{
"MORTA DE AMOR POR DEUS": A VIDA EXEMPLAR DE DONA THOMÁZIA, UMA MULHER LETRADA E DEVOTA QUE MORREU EM LISBOA NO ANO DO TERREMOTO $(1755)^{1}$
}

"Dying for the love of God": the exemplary life of Dona Thomázia, a literate and devout woman who died in Lisbon in the year of the earthquake (1755)

ELIANE FLECK E MAURO TAVARES

Eliane Cristina Deckmann Fleck é doutora em História da América pela PUCRS e professora da graduação e do Programa de Pós-Graduação em História da UNISINOS (efleck@unisinos.br). Mauro Dillmann Tavares é doutor em História pela UNISINOS e professor da FURG (maurodillmann@hotmail.com).

Artigo recebido em 24 de dezembro de 2014 e aprovado para publicação em 5 de maio de 2015. 


\title{
RESUMO
}

Neste artigo, analisamos a obra Vida portentosa da serva de Deus D. Thomázia de Jesus, escrita pelo dominicano João Franco e publicada em 1757. Esta obra, do gênero biográfico, se detém na descrição das características físicas e psicológicas, na vida casta, na extrema devoção e religiosidade de uma mulher letrada portuguesa, apresentando-a como modelo de virtude e santidade. A obra adquire contornos singulares, porque a biografada morreu no ano em que Lisboa foi atingida por um terremoto, e porque seu biógrafo, confessor e diretor espiritual, foi obrigado a reescrever parte do texto, devido à perda dos originais em decorrência do cataclismo.

Palavras-chaVE: Dona Thomázia, santidade, virtudes, escrita, leitura, João Franco.

\begin{abstract}
In this article, we analyze the work Vida portentosa da serva de Deus D. Thomázia de Jesus, written by Dominican João Franco and published in 1757. Belonging to the biographical genre, the work describes the physical and psychological characteristics, the chaste life and the extreme devotion of a religious and literate portuguese woman, presenting her as a model of virtue and sanctity. The work written by the Dominican becomes even more singular, not only because the woman who was the subject of the biography died in the same year in which Lisbon would be hit by an earthquake, but also because its author - and also her confessor and spiritual director - found himself forced to rewrite a large part of the text, due to, precisely, the loss of the originals as a consequence of the cataclysm.
\end{abstract}

KeYworDs: Dona Thomázia, sanctity, virtues, writing, reading, João Franco.

\section{RÉSUMÉ}

Dans cet article nous analysons l'oeuvre Vida portentosa da serva de Deus D. Thomázia de Jésus, écrite par le dominicain João Franco et publiée en 1757. Appartenant au genre biographique, I'oeuvre décrit les caractéristiques physiques et psychologiques, la vie chaste et l'extrême dévouement d'une femme portugaise religieuse et lettrée, la présentant comme un modèle de vertu et de sainteté. L'oeuvre acquiert un contour singulier parce que la biographée mourut à la même année que Lisbonne a été frappée par un tremblement de terre, et parce que son biographe, confesseur et directeur spirituel a été obligé de réécrire une partie du texte en raison de la perte de l'original provoquée par le cataclysme.

Mots-CLÉS: Dona Thomázia, sainteté, vertus, écriture, lecture, João Franco. 


\section{CONSIDERAÇÕES INICIAIS}

E ste texto analisa a obra Vida portentosa da serva de Deus D. Thomázia de Jesus, escrita pelo dominicano João Franco e publicada em Lisboa no ano de $1757 .{ }^{2} 0$ envolvimento de religiosos na produção de biografias - de homens e mulheres considerados santos pela opinião comum - foi bastante frequente ao longo da Idade Moderna. Estas, assim como as hagiografias medievais, que se dedicavam às descrições das vidas de santos, também buscavam "suscitar nos cristãos um comportamento mimético" (Morujão, 1997: 206).

Nosso interesse nesta obra se deve ao fato de ter sido escrita por João Franco, um dos autores mais bem sucedidos de manuais de devoção no Setecentos português, com destaque para Mestre da Vida que ensina a viver e morrer santamente, obra que recebeu diversas edições entre os séculos XVIII e XIX. ${ }^{3}$ Soma-se a isto a constatação de que a obra não apenas evidencia as sensibilidades religiosas reforçadas pela Contrarreforma, divulgando um modelo de vida virtuosa para as mulheres em sociedades marcadamente misóginas, como também aponta para as especificidades da relação que se estabelecia entre confessor/autor e aquele(a) que se confessava e/ou viria a ser biografado(a).

Sendo assim, entendemos que a análise da biografia de Dona Thomázia de Jesus nos permitirá identificar as condutas sociais e morais tidas como ideais, especialmente para as muIheres, propostas pelo dominicano português nesta obra lançada na segunda metade do século XVIII. Inspirados nos pressupostos teórico-metodológicos da História Cultural, procedemos à análise da biografia escrita por João Franco, buscando compreender os discursos religiosos de virtude e moral vigentes no Setecentos português e especular sobre as possibilidades de sua leitura e recepção. ${ }^{4} 0$ atendimento destes objetivos acabou por determinar a estrutura narrativa e argumentativa do artigo, razão pela qual, primeiramente, apresentamos o contexto em que se deu a difusão da literatura religiosa, especialmente de obras que se dedicavam a narrar as "vidas" de homens e de mulheres enfatizando suas virtudes, suas espiritualidades e suas santidades, para, na continuidade, analisar mais detidamente a biografia que João Franco, confessor e diretor espiritual de Dona Thomázia, escreveu. Nela se destacam as descrições de suas características físicas e psicológicas, seu comportamento, seus valores, suas atitudes e seu convívio com outras personagens, que, somados à sua devoção e religiosidade, a tornavam, na visão de Franco, singular e santificada. Por fim, nos debruçamos sobre o contexto de 
produção/escrita da obra de João Franco - em meio aos efeitos do terremoto que se abateu sobre a cidade de Lisboa -, analisamos aspectos formais de sua estrutura e apresentamos algumas possibilidades de leitura e, consequentemente, de interpretação e de apropriação, pelos fiéis letrados, seus potenciais leitores.

\section{LITERATURA E IDEIAS RELIGIOSAS EM PORTUGAL}

Península Ibérica conheceu, na primeira metade do século XVIII, o auge da expansão
de publicações de obras religiosas, entre as quais figuravam os manuais de devoção destinados especialmente aos religiosos e aos leigos que buscavam o aperfeiçoamento moral, segundo a doutrina cristã-católica. Nesta categoria de obras religiosas, as biografias de indivíduos considerados santos ou beatos, principalmente de mulheres, vinham sendo, já desde 0 Seiscentos, constantemente escritas e reeditadas, constituindo-se em gênero de escrita bastante popular na Europa moderna, além de, como bem observado por Leila Algranti (2004: 62), possuírem "caráter pedagógico doutrinal".

A historiografia portuguesa, com especial destaque para os trabalhos da pesquisadora Isabel Morujão, tem se dedicado ao estudo de inúmeras biografias devotas, "claramente enaltecedoras da virtude, da exemplaridade moral e religiosa e mesmo da santidade das religiosas biografadas" (Morujão, 1996: 235). Por biografia devota, Morujão entende aquelas que se ocupam de "pessoas virtuosas a quem o vulgo reconhecia auréola de santidade, mas cujo culto não era oficialmente autorizado". ${ }^{5}$ Este tipo de biografia, segundo a doutora em Literatura Portuguesa, se institucionalizou nos séculos XVII e XVIII, se constituindo

no modelo de outras escritas e também num horizonte de espera para os leitores, sequiosos de aí encontrarem exemplos extremos do amor a Deus e marcos que de alguma forma dessem a perceber a santidade que a alma biografada foi chamada a viver ao longo da sua vida (Morujão, 1996: 237).

Se, na França, essa literatura religiosa era publicada e consumida desde pelo menos o século XVI (Julia, 1999), em Portugal e na Espanha também eram editadas obras de teor místico e espiritual, em sua maioria, escritas diretamente em português ou castelhano por religiosos de ordens religiosas ou traduzidas em diversos idiomas, como o latim, o alemão, 0 francês, o inglês e o italiano.

A religiosidade e a vivência cristã esperadas pela Igreja em relação aos fiéis previam a devoção a inúmeros santos, conduta que foi reafirmada com a Contrarreforma, que muito contribuiu para a difusão do espelho que representavam os santos para a vida dos cristãos. 
Isto parece explicar por que os autores deste gênero de obras religiosas passaram a empregar de forma tão recorrente os termos "santamente", "santificada" e "santidade", associados à imitação dos santos e à adoção de condutas e valores exemplares. ${ }^{6}$

Havia, pois, no século XVIII, à disposição dos fiéis, diversos modelos de santidade7 que a Igreja Católica fazia questão de divulgar. E existia também considerável interesse do público católico em conhecer, ler e ouvir sobre estes exemplos de santidade, entre os quais se encontravam Santa Catarina de Siena (1347-1380) e Santa Teresa d'Ávila (1515-1582), duas famosas santas largamente citadas em livros religiosos do século XVIII e analisadas pela historiografia (Borges, 2012: 10). Em razão disso, passaram a ser cada vez mais frequentes, no contexto Setecentista, os relatos de vida de mulheres ${ }^{8}$ - geralmente enclausuradas ou simplesmente recolhidas - que conseguiam alcançar um tão elevado nível de contemplação, capaz de as tornar exemplos de santificação. ${ }^{9}$

Em geral, a historiografia clássica considera que na Europa contrarreformista muitas mulheres devotavam suas vidas a Deus, consagrando-as ao amor do próximo e ao de Cristo (Farge; Davis, 1991: 15). Essas mulheres, dotadas de sensibilidade devocional contemplativa, regravam suas vidas com orações, meditações, comunhões e confissões, podendo chegar ao grau máximo da comunicação pessoal com Deus, o chamado êxtase (Kessel, 1991: 193).

Muitas foram as obras sobre as vidas dessas mulheres consideradas santas publicadas pelo mercado livreiro português, ${ }^{10}$ em sua maioria escritas por seus confessores ou diretores espirituais. ${ }^{11}$ Entre as obras que versavam sobre estas mulheres, destacamos ainda a obra Jardim do ceo, escrita por Madre Maria Benta do Ceo, que foi analisada pela historiadora Lígia Bellini (2006: 82-83), e que trazia um conjunto de 20 trajetórias femininas modelares, freiras do Convento de Nossa Senhora da Conceição de Braga, de 1629 a 1764. Também Isabel Morujão, interessada em relatos de morte na clausura, nos apresenta uma lista de várias dessas biografias de religiosas portuguesas. ${ }^{12}$

Considerando que muitas destas biografias de mulheres tidas como santas foram escritas nos claustros femininos e eram destinadas àquelas que neles viviam,,$^{13}$ é preciso considerar o contexto de escrita e de divulgação, ou seja, de leitura, como faremos mais adiante neste artigo. Por ora, cabe destacar que a santidade de Dona Thomázia residia em sua "espiritualidade mística", ou seja, na experiência vivenciada com o sagrado, expressa através de relatos escritos ou de confissões pessoais. As experiências místicas de Dona Thomázia, suas vivências com o transcendente (Manganaro, 2010: 09), diziam respeito a um modo íntimo de se relacionar com Deus, de maneira a alcançar a plenitude possível da vivência religiosa (Japiassu, 2006: 189).

Mesmo que a mística, a elevação da alma até Deus, através da oração ou de outras expressões de fé, fosse muito valorizada pela Igreja Católica, é preciso lembrar que no período 
moderno a própria Igreja procurou controlar certas práticas religiosas dos fiéis, objetivando "conduzir as condutas, quer de leigos quer de eclesiásticos" (Braga, 2010: 308), numa tarefa que se caracterizava

pela utilização de formas e instrumentos de difusão do discurso religioso, umas de caráter repressor, tais como visitas pastorais e inquisitoriais e censura de livros, e outras de caráter pedagógico e persuasivo, tais como missões do interior, pregações, ensino da doutrina e confissões, sem esquecer a divulgação de livros de devoção, catecismos, hagiografias, imagens e até peças de teatro com fins evangelizadores.

Ao evidenciarem a preocupação com o respeito à ordem disciplinar, às normas de conduta e à vida contemplativa dos fiéis, estas iniciativas da Igreja revelam-nos que os desvios, as infrações e os desrespeitos eram bastante comuns, demandando intervenção. ${ }^{14}$ Foi também com este sentido pedagógico, disciplinar e persuasivo, visando à conformação da espiritualidade dos fiéis e, especialmente, das mulheres leitoras que viviam nos espaços conventuais, que a obra Vida portentosa foi escrita e publicada. ${ }^{15}$

A leitura destes livros, dirigidos especialmente às mulheres, deveria influenciar as práticas de contemplação, oração e meditação, de modo a garantir não apenas a perfeição e a pureza espiritual, mas também um controle dos modelos de santidades populares, geralmente associados às acusações de práticas como a bruxaria e as superstições.

Entre as biografias de veneráveis, beatos e santos escritas e publicadas no século XVIII, encontramos a de Dona Thomázia, descrita por João Franco como uma "venerável serva de Deus", logo, merecedora de veneração, admiração, respeito e estima por suas virtudes. Outras religiosas portuguesas também ganharam fama de santidade no período moderno, merecendo estudos sob diferentes enfoques e abordagens teórico-metodológicas. Isabel Morujão (1996: 261), por exemplo, analisou duas biografias de religiosas que "agiram santamente sobre as suas comunidades" buscando progredir na vida espiritual e exerceram uma "ação santa" nos mosteiros onde viviam, movidas pela ideia de evoluir e progredir no "amor de Deus" (Morujão, 1996: 236).

\section{DONA THOMÁZIA DE JESUS}

Liografia de Dona Thomázia segue a narrativa cronológica de sua vida - da infân-
à morte -, enfatizando suas virtudes, obras, práticas caritativas e religiosas, seus conflitos e ansiedades pessoais. Neste sentido, a obra se assemelha às biografias de outras religiosas do período, as quais, segundo Algranti (2004: 67), se caracterizam "pela descrição de suas premonições, sonhos e interpretações de fatos referentes" à sua vida. 
Por se tratar de uma mulher letrada - como inúmeras outras que viviam recolhidas em conventos - é importante ressaltar que Dona Thomázia era mais do que leitora, sendo também escritora. Franco (1757: 32) confirma que Thomázia escrevia muito, ao relatar que tinha "muitos papéis seus na cela". Além disso, a narrativa de Franco sobre a "vida" da religiosa se baseou em escritos deixados pela própria Thomázia. Através desta prática bastante comum nos recolhimentos e conventos, mulheres como ela deixavam um testemunho de sua fé e de suas experiências espirituais, visando à construção não apenas de sua auto-imagem, mas também da instituição à qual pertenciam. ${ }^{16}$

A portuguesa Thomázia Maria de Araújo, ou simplesmente D. Thomázia de Jesus, passou boa parte da vida em recolhimentos da cidade de Lisboa, tendo adotado o hábito de terceira Dominica, no Mosteiro do Salvador, 20 anos antes de sua morte. Na gravura abaixo (imagem 1) - de autoria desconhecida -, que ilustra a obra Vida portentosa, ela aparece com um crucifixo ao peito e com os olhos baixos, em uma postura representativa da vida em oração que adotou na clausura, mesmo sem ter sido freira. ${ }^{17}$ Essa experiência conventual a diferenciava da maioria das biografadas à época, que haviam pertencido a alguma ordem religiosa, condição que geralmente estava associada ao atributo de santidade.

Imagem 1: Dona Thomázia de Jesus

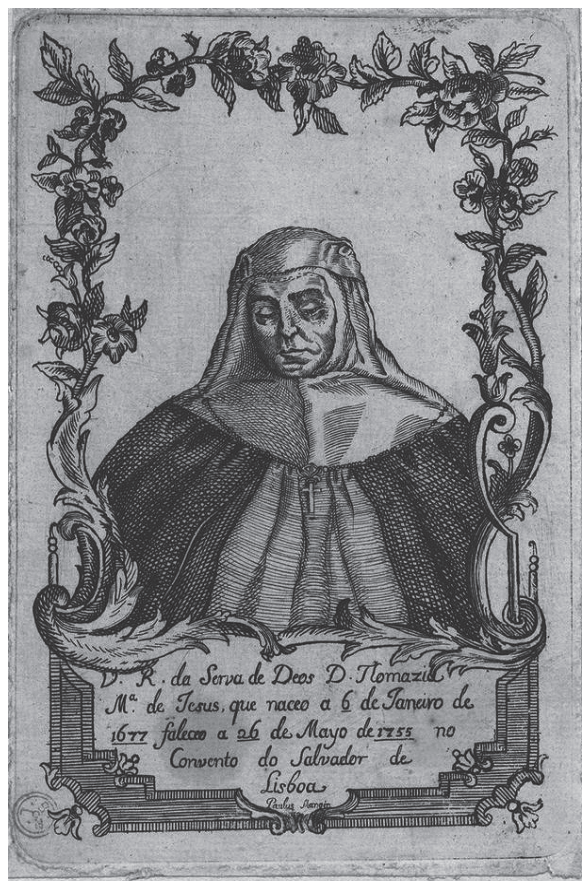

Fonte: http://www.bnportugal.pt/ 
O Mosteiro do Salvador de Lisboa, fundado no final do século XIV, era um convento feminino e pertencia aos Dominicanos (Ordem dos Pregadores). A documentação deste Convento, referente ao período que vai do século XIV ao final do século XVI, encontra-se no Arquivo da Torre do Tombo, em Lisboa. Sabe-se que o mosteiro foi fechado no século XIX, em função da morte da última freira, e que a documentação que remonta aos séculos XVII, XVIII e XIX não foi ainda, infelizmente, localizada.

A vida de Dona Thomázia descrita pelo dominicano João Franco pode, portanto, nos revelar como viviam as mulheres recolhidas neste convento e em outros do Setecentos, além de permitir a reconstituição do comportamento social esperado de uma mulher. Na Idade Moderna, a mulher honrada deveria possuir conduta digna, construída, segundo Maria Marta Lobo de Araújo (2000: 17-18), "sobre uma plataforma de valores que privilegiavam o recato, o pudor, a honestidade e os bons costumes". Sobre o gênero feminino recaíam cobranças sociais, como o ser socialmente reputada, gozar de bom nome e estar isenta de qualquer fama. $A$ mulher devia ser "pudica nos dizeres (...), ser trabalhadora, obediente, conformada e abster-se de manter conversas prolongadas com homens". À literatura religiosa cabia a defesa destes valores, na medida em que associava "as mulheres a sentimentos de compaixão, doçura, amor e obediência aos pais e aos maridos".

Filha de pais honrados, nobres e católicos, Thomázia nasceu na Rua dos Ourives da Prata, no dia 6 de janeiro de 1677, tendo sido batizada na Freguesia da Madalena, região central de Lisboa, como se pode perceber na imagem 2, que a ilustra e localiza geograficamente.

\section{Imagem 2: Freguesia da Madalena}

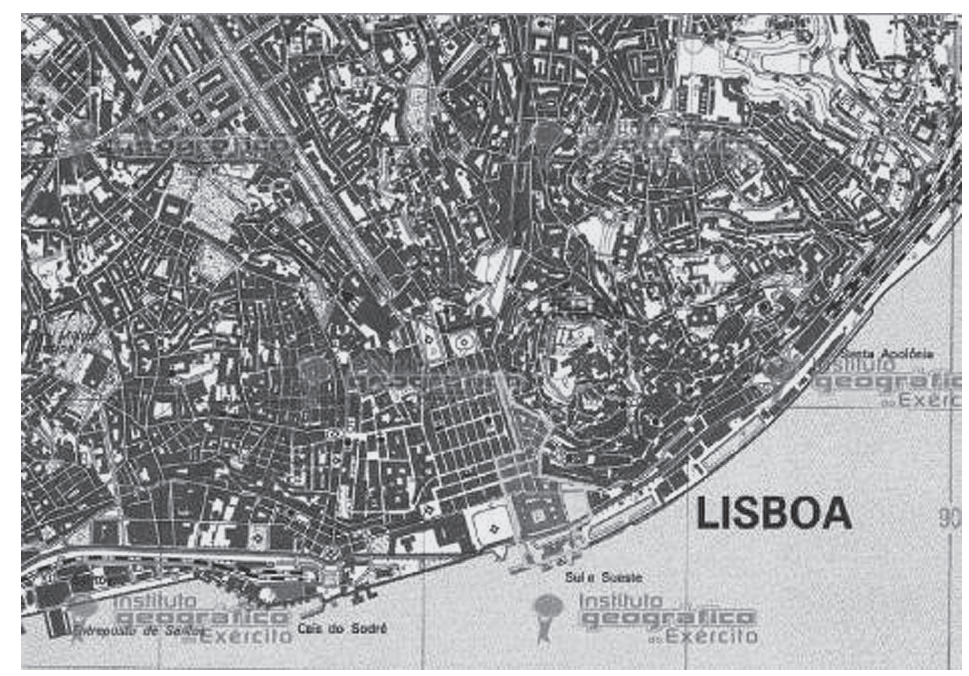

Fonte: http://jsdseccaoilisboa.wordpress.com/autarquicas-2009/freguesias/freguesia-da-madalena/ 
Aos 14 anos de idade, os pais a casaram com um capitão de mar e guerra, chamado João da Silva Manoel, homem bem mais velho ou, nas palavras de Franco, "já de idade varonil" (Franco, 1757: 9), que costumava viajar ao Oriente, levando e trazendo Vice-Reis. Como a vida de viajante o obrigava a afastar-se do lar por alguns meses, ou até mesmo por anos, durante essas longas viagens, o marido - que chegou a ficar três anos longe de Portugal - deixava a esposa recolhida em conventos de Lisboa, o que permitiu que ela não apenas conhecesse o recolhimento da Misericórdia, mas também outros, além do convento do Salvador. ${ }^{18}$ Apesar dos longos períodos de afastamento, do casamento de 15 anos nasceram as filhas Filippa, Maria e Ignez, sendo que a última morreu ainda criança. A morte do marido representou uma nova fase na vida de Thomázia, que, segundo Franco, deu "graças" por "se ver livre das prisões do matrimônio", 19 pois devia, enquanto esposa, "sujeições, humildades e obediências" ao marido20 (Franco, 1757: 06-09).

Mulher de poucas palavras, quase sempre calada, Dona Thomázia dormia pouco, não possuía cama e passava as noites rezando e contemplando, especialmente, a Deus, Nossa Senhora, São Miguel e São José. Passava suas noites no Coro, fazendo exercícios da cruz, as estações da Madre Maria de la Antigua, rezando o terço, acompanhada de alguma freira, além de outras devoções (Franco, 1757: 40).

Na narrativa de Franco ganham especial destaque suas características morais, psicológicas e religiosas. Apresentada como "mansa", resignada, humilde, silenciosa, calada ${ }^{21}$ e pacífica, Thomázia se autorrepresentava como "sempre alegre", embora Franco a tenha descrito também como assustada e com muitos medos (Franco, 1757: 34). Os últimos 40 anos de sua vida foram marcados por constante penitência, pois abdicou do consumo de carne e adotou a prática do jejum, alimentando-se apenas de pão e água durante três dias da semana. ${ }^{22}$ Nos demais dias, alimentava-se somente uma única vez por dia, no jantar, que consistia de duas sardinhas, pão, queijo, saladas e frutas, exceto as consideradas mais saborosas, como os figos e os melões. Nos últimos dois meses de vida, de acordo com Franco, Thomázia quase não comia, e mesmo uma xícara de chocolate lhe custava muito. Costumava andar encolhida, evitando ao máximo se despir, já que apenas "de semanas em semanas" trocava suas roupas (Franco, 1757: 20). Estas eram renúncias necessárias à preservação de uma vida santa, na medida em que conjugavam devoção com sofrimento pessoal, conduta muito próxima das práticas de penitências impostas por confessores aos pecadores.

Além de se autocondenar, Thomázia percebia o sofrimento como merecimento e como aplicação da justiça divina. Esta percepção a levou a usar um colete de cilício - bem apertado - por 15 anos, o que the trouxe problemas respiratórios, tratados através de 16 sangrias. ${ }^{23} \mathrm{~A}$ fim de "se vingar do seu corpo", queimava-se várias vezes ao dia, recorrendo ao fogo do lacre, 
que pingava 15 vezes "na sua carne", por serem 15 os mistérios do Rosário de Maria (Franco, 1757: 23-24). Esta conduta reforça o observado pelo historiador William Martins (2013: 213), para quem "as mortificações corporais, como jejuns e penitências, tornaram-se um instrumento recorrente para garantir a submissão do corpo e do espírito a um ideal de vida santa".

Em suas conversas com Deus, relatava as recomendações feitas pelo confessor, reclamava contra o que considerava indigno da fé, embora reconhecesse que seus pedidos a Deus eram atendidos, uma vez que o Senhor "fazia grande negócio com ela". o fato de o céu, percebido como "oficina dos milagres", atender às orações de Thomázia, acabou por lhe conferir certa fama no convento: passou a ser requisitada por diversos motivos, especialmente para a cura de problemas de saúde, mas também para pregar e desenganar as recolhidas, auxiliando na eliminação das "vaidades do mundo" e na edificação das "delícias do céu" (Franco, 1757: 16-18).

Para reforçar sua humildade, Franco destacou a forma como Thomázia se autorrepresentava em seus escritos. Em todos eles ela se intitulava "tola", uma "firma", conforme dizia Franco, que demonstrava o "desprezo de si". ${ }^{24}$ A humildade e a paciência da "serva de Deus" teriam sido demonstradas também ao confessor anterior de Thomázia, que Ihe havia aplicado uma forte bofetada, ao que ela teria oferecido a outra face, causando assim admiração e espanto na "comunidade toda" (Franco, 1757: 31-32).

Franco não descuidou de descrever seus sonhos, visões e diálogos com a corte celeste e com os mortos. Thomázia sonhava constantemente com Nossa Senhora, enxergava Jesus Cristo, comunicava-se com os anjos, recebia recados e instruções diretamente de Deus e, também, a consolação de santos e anjos. 0 "Senhor" se apresentava a ela "em forma humana com tal formosura", e assim também o Espírito Santo, que se apresentava na figura de uma "pomba tão linda" (Franco, 1757: 43). Com frequência, ela tinha visões dos seus padrinhos espirituais, São José (considerado o Príncipe dos santos) e São Miguel (considerado o Príncipe dos anjos). Estas experiências místicas, colóquios e visões, eram encarados de forma diversa pela hierarquia eclesiástica, dependendo da posição ocupada pelos avaliadores. ${ }^{25}$ Diretores espirituais e confessores costumavam encarar tais relatos e vivências como confirmações de elevação espiritual, fruto de uma vida contemplativa e devota; por outro lado, julgadores do Tribunal da Inquisição consideravam tais experiências fortes motivos de denúncia a respeito de possessões ou influências demoníacas. ${ }^{26}$

A extrema devoção podia, então, ser encarada por padres e confessores como possessão demoníaca, o que chegou a ocorrer com Thomázia quando um de seus primeiros confessores a considerou "endemoniada", empregando exorcismos. Tal procedimento se deveu à convicção de que tamanha virtude e bondade, seguida de visões e revelações, era obra do demônio, acompanhada dos "infinitos enganos" existentes na "Igreja de Deus" (Franco, 1757: 29). Esta experiên- 
cia prévia de Thomázia levou João Franco a destacar seu trabalho para desenganá-la, levando-a a ter consciência dos enganos existentes "nesta matéria de sentimentos altos" e de que entre as muitas revelações "apenas haverá uma verdadeira" (Franco, 1757: 30). Neste sentido, apresentou positivamente seu trabalho de confessor, afirmando que "procurou adiantá-la e aperfeiçoá-la nos rigores da vida [0] quanto Deus sabe" (Franco, 1757: 23), enfatizando a impossibilidade de sua adoração como santa, tida como "comédia" e "loucura":

Que espera que Ihe faça o confessor? Espera que a ponha sobre um altar, que the ponha duas velas aos lados (...) e que o confessor se ponha de joelhos a adorar a santinha? Veja que gaIhofa faria o diabo, se vira esta comédia. Não, senhora, não devemos fazer estas loucuras: devo encaminhá-la pelo caminho seguro (Franco, 1757: 30)

Na obra, Franco relata os diálogos que Thomázia teria travado com Deus, destacando os sentimentos envolvidos e acrescentando que, por diversas vezes, Ele teria rido de sua ingenuidade e inocência. 0 biógrafo apresenta o divertimento e entretenimento de Deus, que, com frequência, mostrava "que se estava rindo" (Franco, 1757: 45) de Dona Thomázia - situação que deve ter caracterizado também o convívio do próprio João Franco com a devota mulher.

Thomázia expressava saudades do divino e chorava constantemente, desejando deixar este mundo e se alegrando "contentíssima" com as doenças que a acometiam e prenunciavam a aproximação da "hora de partir desta vida", pois já estava "morta de amores" por Deus (Franco, 1757: 44). Além disso, Thomázia dizia ser repreendida por Deus por certos comportamentos, como se pode constatar nas seguintes passagens: "Vai para onde estavas"; " ali a prendeu o Senhor, como fazia muitas vezes sem a deixar ser senhora de si, e a repreendeu das suas faltas"; " eu não quero que tu faças pecados" (Franco, 1757: 50).

Nas conversas que tinha com Deus, Thomázia desejava a morte com veemência e anunciava ao divino a sua condição de "morta de amor", aproximando-se da "ansiedade" escatológica, tal como proposto por Isabel Morujão (1997: 215) ao comparar "a ânsia ou o desejo do encontro com Deus" ao sentido de ansiedade, especialmente daquele "experimentado no momento da morte". Assim, ao afirmar que "já não vivia, porque estava morta de amores por ele" (Franco, 1757: 44), Thomázia expressava o "desejo da própria morte, como momento supremo pelo qual a alma" se uniria "ao Criador, numa liberdade sem limites" (Morujão, 1997: 234).

Espíritos de freiras também se comunicavam com Thomázia, com o objetivo de alegrá-la, diverti-la ou, simplesmente, fazer-lhe visitas. Na solidão do claustro, Thomázia invocava as freiras mortas, sob a alegação de que ela sentia medo dos vivos, não dos mortos: "Irmãs, vinde estar comigo, que eu das vivas é que tenho medo, que de vós não" (Franco, 1757: 41). 


\section{DONA THOMÁZIA E O CONVENTO DO SALVADOR DE LISBOA}

fama de santa, tão presente na biografia escrita por João Franco, parece ter se confir-
mado entre as religiosas do Convento do Salvador de Lisboa com as quais Thomázia conviveu durante anos, fundamentalmente a partir das curas que realizava.

Diante de problemas graves de saúde, recorria-se a ela imediatamente: "Chamem lá Dona Thomázia, a Santa"27 (Franco, 1757: 18). Entre os muitos remédios que ela "aplicava" às enfermas, estava a invocação de Jesus, pois para as "enfermidades sem remédio" a cura deveria se dar através da fé, do exercício da oração, da realização dos terços do Rosário, do rendimento de súplicas, do acendimento de velas, da prática de promessas, do toque do manto de Nossa Senhora, da crença nos milagres ou do sinal da cruz. Através de suas orações, ela teria curado um enfermo fazendo-o suar bastante, de modo que "ensopou os colchões e em breves dias melhorou" (Franco, 1757: 69). Franco registrou também algumas "receitas" empregadas para promover a cura, tais como o uso de água benta e a aplicação de folhas de alface sobre queimaduras.

A realização de curas ou o emprego de certas práticas curativas por religiosas do século XVIII nem sempre foi bem vista pela Igreja Católica, sendo também motivo de escárnio, como se pode constatar na reação do confessor ao descobrir que Thomázia aplicava folhas de alface em queimaduras: "pôs-se a rir e a serva de Deus desconfiou de o ver rir" (Franco, 1757: 64). 0 caso de Joana Maria, por exemplo, analisado pela historiadora Célia Borges (2012: 57-58), se aproxima do relatado por João Franco. Joana, que integrava a Ordem Terceira de São Francisco, foi presa pela Inquisição de Coimbra em 1719, sob a acusação de que realizava milagres e curas duvidosas, recorrendo à água, às orações e ao pó produzido com as flores do altar de Santa Ana. Segundo os inquisidores, as prováveis curas resultavam de algum pacto demoníaco firmado por Joana, o que parece confirmar a ideia de que o demônio possuía poderes curativos.

Se, no caso de Thomázia, as curas por ela realizadas serviram como reforço argumentativo para sua elevação espiritual, pode-se também, através delas, identificar quais as enfermidades que acometiam as religiosas do Convento do Salvador de Lisboa em meados do século XVIII. Entre as relacionadas pelo dominicano, aparecem "convulsão na cabeça", "dor de pedra", enfermidade nos olhos, vômitos, "garrotilho" [garganta], dor de estômago [chamada de cardealgia], "febre catarral", dor de cabeça, tosse, febre maligna [terçã], nódoas, herpes e tísica.

Estes relatos também nos revelam o quanto o trato com os enfermos era função indesejada entre as mulheres enclausuradas no convento, apesar de ser tido também como função nobre, como no caso de Santa Catarina de Siena. Poucas aceitavam a função de enfermeira, pois ela envolvia cuidados aos moribundos e despesas que necessariamente deveriam ser por elas 
assumidas. Este aspecto pode ser observado na seguinte passagem: "Soror Catharina Ignácia de Jesus, religiosa do mesmo convento de Salvador, serviu um ano o ofício de enfermeira com muita má vontade pelos muitos trabalhos e gastos que tem aquele ofício" (Franco, 1757: 73). Também Lígia Bellini (2006: 105), ao analisar obra Jardim do ceo, observou que, apesar de os cuidados prestados às irmãs doentes integrarem a rotina conventual, poucas das mulheres biografadas desempenharam esta função. No Convento do Salvador, Thomázia conviveu e compartilhou suas experiências com inúmeras freiras. Na obra Vida portentosa são citados diretamente 18 nomes de religiosas, além de três confessores. Por desconhecermos o número e, especialmente, o nome das demais religiosas que viviam no Convento do Salvador em meados do século XVIII, não temos, infelizmente, como definir o perfil social das enclausuradas. Mas se considerarmos Dona Thomázia e os dados extraídos de outros estudos realizados sobre clausuras femininas, podemos supor que a maioria das mulheres que lá se encontravam pertencia à elite portuguesa. ${ }^{28}$

Entre as por ela referidas, encontramos Soror Maria da Soledade, que ocupava o cargo de governanta do Convento, Soror Anna da Glória, que teria sido cantora-mor, e Soror Catharina Ignácia de Jesus, enfermeira. 0 relato de Franco refere ainda outras franjas da população que circulava pelos mosteiros de Lisboa, como os médicos cirurgiões, as lavadeiras e as crianças. Estes, certamente, puderam conviver - de forma mais ou menos intensa - com a devota Thomázia, e muito provavelmente foram testemunhas ou legitimadoeas da sua fama de santidade.

Quanto aos confessores que antecederam João Franco - "o que agora the escreve a vida" -, que "a governou por alguns vinte anos", Thomázia teve outros que a "apertaram bem" e com os quais conviveu. 0 primeiro de seus confessores foi um provincial de S. Francisco, função posteriormente assumida pelos frades de S. Domingos, como o padre José do Sacramento e o padre José da Purificação, considerado "poeta", que a teria, certa vez, repreendido em público por ter manifestado o desejo de comer alguma guloseima no domingo.

Para além da reconstituição do perfil e do cotidiano das mulheres enclausuradas, do levantamento das enfermidades que as atingiam e das práticas curativas por elas empregadas no Convento do Salvador de Lisboa, a obra Vida portentosa nos permite refletir também sobre o contexto em que foi escrita e sobre as prováveis leituras que seus leitores dela fizeram.

\section{TeXTo, CONTEXTO E LEITURA}

$\mathrm{D}$ ona Thomázia levava vida casta, obediente e pobre como a maioria das dedicadas religiosas de seu tempo, sobretudo aquelas que foram consideradas merecedoras de uma biografia. A obra escrita pelo dominicano adquire contornos ainda mais singulares não apenas porque a religiosa biografada morreu no mesmo ano em que Lisboa foi atingida por 
um terremoto, mas porque seu biógrafo - e também confessor e diretor espiritual - se viu obrigado a reescrever boa parte do texto, devido justamente à perda dos originais em decorrência do cataclismo. A biografia de Dona Thomázia foi, portanto, fruto de uma reescrita, de uma nova consulta aos documentos que sobreviveram ao abalo sísmico, de uma rememoração do dominicano João Franco.

Abaixo transcrevemos o lamento de Franco - exposto na primeira página da obra diante da perda dos "papéis originais" e o reconhecimento da graça divina, que teria possibilitado sua reescrita, como se pode constatar na imagem 3.

Segunda vez pegamos na pena para dar à luz esta prodigiosa Vida, por se ter queimado o primeiro trabalho na calamidade, que chorou esta Corte de Lisboa, no primeiro de Novembro de 1755; porém como N. Senhor com alta providencia conservou até aqui os papeis originais desta sua serva, que ela fez de mão própria por ordem, e obediência aos seus confessores, sendo Deus admirável nos seus servos, e tendo grande gloria de que se saibam as maravilhas, que neles faz, não é justo que roubemos a Deus esta glória, e por isso (ainda que com pouca saúde) tornamos a escrever o mesmo segunda vez (Franco, 1757: 1).

\section{Imagem 3: Primeira página da obra Vida portentosa}

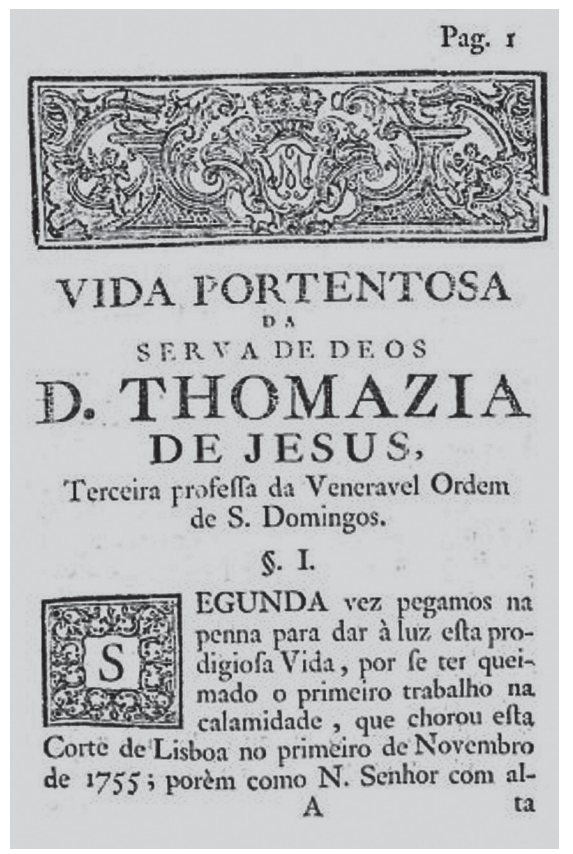

Fonte: FRANCO, João. Vida portentosa da serva de Deus D. Thomazia de Jesus. Lisboa, na oficina de Miguel Manescal da Costa, impressor do Santo Ofício, 1757. 
Como a primeira versão da biografia foi queimada em novembro de 1755 e a licença do Santo Ofício data de julho de 1756, é possível que João Franco tenha reescrito a obra em menos de seis meses, com base nos documentos que sobreviveram ao terremoto. ${ }^{29}$ Mas sua licença "para correr" ocorreu nove meses depois, apenas em abril de 1757, após passar pelas aprovações do Ordinário e do Paço, o que nos leva a perceber que entre a escrita e a publicação poder ter transcorrido mais de um ano.

A obra foi dedicada a D. Pedro (1717-1786), ${ }^{30}$ infante de Portugal, pelo fidalgo da casa da Majestade e, também, seu "guarda-roupa", Caetano de Andrada Pinto. Na dedicatória, Andrada Pinto - em tom elogioso - afirma que as virtudes de D. Pedro eram similares às que Dona Thomázia possuía, destacando que esta havia realizado rogativas a Deus por sua Alteza, do mesmo modo que observava "piamente a contempla a minha devoção".

Na abertura, a obra traz dois poemas: um soneto, escrito pela Soror Francisca Juliana, uma religiosa do Mosteiro do Salvador que revela a admiração, contemplação e saudades ("dor da ausência") de Dona Thomázia; e outro poema anônimo, de uma "veneradora das suas virtudes", que enfatizava a morte, os mistérios e os milagres, atribuindo à Dona Thomázia a condição de santa.

Vida portentosa é um livro pequeno, tanto por seu formato - $15 \mathrm{~cm}$ - quanto por seu número de páginas, apenas 85 . Trata-se, portanto, de um pequeno manual, facilmente transportado e manuseado, o que possibilitava uma leitura intensiva por aquele que o possuísse ou a ele tivesse acesso. A Biblioteca Nacional de Portugal conta com seis exemplares desta edição de Vida portentosa, informação relevante quando consideramos as possibilidades de sua circulação. Apesar de não termos dados sobre a tiragem desta edição da obra e indícios de sua circulação em Portugal, sabemos, através de informação que consta no volume três do Diccionario bibliográphico portuguez, que seu autor, Innocêncio Francisco da Silva, possuía "um bom exemplar, em papel de grande formato" da Vida portentosa (1859: 279), o que nos oferece evidências de sua leitura e manuseio.

Na contracapa da obra que consultamos, encontramos a assinatura [a bico de pena] de Soror Margarida Maria de Jesus, do que inferimos que o exemplar tenha pertencido a ela. Já na parte de trás, existe um pequeno pedaço de folha colado que traz uma oração manuscrita, da qual, devido ao estado de conservação, consegue-se identificar somente algumas palavras, tais como Santa Teresa, Santa Luzia, Santa Rosa, Santo Antônio, anjos do céu e uma rogativa a Nossa Senhora "pelas dores de nossa alma". Considerando-se a prática muito comum no período, pode-se supor que Soror Margarida Maria de Jesus tenha compartilhado o livro ou mesmo sua leitura com outras religiosas, como apontam os estudos do historiador norte-americano Robert Darnton (2014), que destacam a intensa circulação não somente de obras religiosas, mas também de poesias na Paris do século XVIII. 
Neste mesmo século, houve - como bem assinalou Roger Chartier (2002: 99) - uma significativa transformação na prática e nos modos de ler. Além da leitura intensiva e da retomada constante das poucas obras que circulavam e que eram lidas, ganhou destaque a leitura extensiva, devido à expansão da atividade editorial, ao aumento da alfabetização e ao maior consumo de livros pelos leitores/ouvintes. Do crescimento de publicações observado em Portugal, infere-se que a leitura de manuais de devoção também tenha sido incrementada a partir de meados do século XVIII (Araújo, 1997). Há que se considerar, contudo, que as leituras poderiam vir acompanhadas de experiências de memorizações e declamações e que 0 conhecimento do conteúdo de obras religiosas, como a Vida portentosa, também pode ter sido transmitido oralmente (Darnton, 2014: 145). Desta ampliação do público leitor e/ou ouvinte no Setecentos decorreram diversas apropriações e interpretações dos materiais impressos, com destaque para as obras religiosas, que visavam à orientação das condutas dos fiéis.

Refletindo sobre os efeitos da maior circulação e consumo do livro por parte de grupos populares e, especialmente, das possíveis apropriações, Juan Cubíe (2012 [1768]: 29), em obra publicada em 1768, assim se pronunciou: "hoje em dia todos são críticos e o maior deles costuma ser o mais ignorante", não havendo "um ajudante de cozinha que, sabendo ler, não se meta a criticar quando obras saíam a público". É preciso, no entanto, considerar que não apenas os leitores comuns, tratados como ignorantes e sem erudição por Cubíe, se manifestavam publicamente sobre o que haviam lido ou ouvido. 0 pensamento crítico iluminista, que incentivava o questionamento e a colocação de teses à prova, promoveu uma ampla manifestação de todos os setores sociais, inclusive daqueles ligados à Igreja.

Os possíveis leitores da obra Vida portentosa talvez fossem, em sua maioria, indivíduos religiosos do sexo feminino, reclusas ou recolhidas em conventos, mas não podemos desconsiderar as mulheres leigas letradas ou simples ouvintes que integravam a sociedade lisboeta. Vale destacar que, apesar da impossibilidade de avaliarmos a efetiva recepção desta biografia escrita por João Franco, existe já uma consagrada produção historiográfica que aponta para a prática da leitura e audição de livros religiosos nos conventos portugueses. ${ }^{31}$ É preciso, também, considerar que o dominicano João Franco era reconhecido em Lisboa pelo sucesso editorial de suas obras e sermões, logo não seria descabido supor o efetivo uso, manuseio e leitura da Vida portentosa por parte dos fiéis, especialmente mulheres.

Como já observado, a obra que narrou a vida de Dona Thomázia foi, de fato, dedicada às leitoras católicas, que deveriam orientar suas vidas a partir de sua conduta exemplar e virtuosa. Como uma leiga recolhida em convento, Dona Thomázia foi apresentada como um arquétipo ideal de conduta cristã, de prática da caridade, de tempo dedicado às devoções e às orações, de prática frequente da confissão e de obediência ao confessor. 
Portanto, por mais que sejam - e realmente são - múltiplas as possibilidades de leitura e interpretação de um texto, bem como sua provável sujeição ao tempo e ao esquecimento (Certeau, 1994: 270), a narrativa de João Franco propunha uma leitura possível, a partir do sentido que seu próprio autor atribuía ao texto. Se o entendimento de cada leitor é dinâmico, distinto e provisório - e não dispomos aqui de quaisquer evidências práticas dos modos como se realizaram as leituras de Vida portentosa -, é também certo que o público leitor destinatário - pelo contexto ou pelo interesse sócio-religioso - compartilhava com João Franco as prerrogativas de virtude e santidade pregadas por ele e pela Igreja Católica no Antigo Regime.

\section{CONSIDERAÇÕES FINAIS}

F oi na condição de confessor da leiga devota Dona Thomázia, tida como modelo de conduta virtuosa a ser seguido, que João Franco - como tantos outros religiosos do período moderno - se dedicou à escrita de sua biografia. Ela talvez não tenha alcançado grande fama de santidade entre os portugueses católicos durante sua vida e após a morte, mas, segundo o "testemunho" de João Franco, era reconhecida como tal no Convento do Salvador, em Lisboa. A narrativa edificante da "vida" de Dona Thomázia por João Franco não pode, contudo, deixar de ser também compreendida como uma autopromoção e divulgação de seu trabalho como confessor, com destaque para o conhecimento que tinha da vida de seus confessados e para o acolhimento e a condução bem sucedida que praticava - como orientador espiritual - nas coisas da fé.

Se, por um lado, no século XVIII reconhecia-se que as mulheres eram mais inclinadas à piedade, atribuindo-se a elas o epíteto de sexo devoto (Cubíe, 2012 [1768]: 40), por outro, a valorização de certo comportamento devoto e moral feminino, como se observa na obra Vida portentosa do dominicano Franco, significava o afastamento da consagrada visão misógina e detratora, que questionava as capacidades físicas e intelectuais femininas (Silva, 2011: 35).

A santidade de Thomázia teria, contudo, outro elemento que viria reforçá-la, pois João Franco atribuirá à "alta providência" a preservação dos "papeis originais" - nos quais se basearia para escrever a biografia - em meio ao terremoto de 1755, que tantos prejuízos e mortes havia causado aos lisboetas. Na percepção do dominicano, sua conservação deveria ser interpretada como um sinal divino da necessidade de divulgação da mensagem evangélica através dos registros da vida exemplar daquela mulher devota.

De acordo com Franco, à devoção e à extrema religiosidade de Dona Thomázia somavam-se a conduta virtuosa, as experiências místicas e o cuidado e a cura de enfermos, apontando para sua santidade e vida exemplar que deveria ser imitada por outras religiosas. Tal 
como na biografia da religiosa Paula Jerônima, analisada por Leila Algranti (2004: 68-69), na obra do dominicano João Franco o destaque estava na reafirmação do modo de vida de Dona Thomázia, dos seus valores cristãos e do cultivo da fé no divino. Além de participar do coro, rezar constantemente, recolher-se a uma cela separada, atender as enfermas, aconselhar e desenganar as recolhidas, confessar-se frequentemente e falar muito pouco, ela havia optado por alimentar-se uma única vez por dia, dormir no chão, trocar de roupa raramente e cumprir rigorosamente as penitências, queimando-se com frequência.

Thomázia morreu aos 78 anos, já bastante idosa, se considerarmos a expectativa de vida da época. Nos anos finais de sua vida, padeceu de inúmeras moléstias e dores, ficando "em artigos de morte" pelo considerável tempo de nove semanas e dois dias. Tal resistência foi atribuída muito mais aos mistérios da fé do que aos efeitos dos remédios recomendados por seu médico Antonio Isidoro da Nóbrega, que cuidou de sua saúde até os últimos instantes (Franco, 1757: 77).

0 momento de sua morte foi relatado de acordo com o modelo edificante comum em relatos de passamentos de leigos ou religiosos portadores de santidade. E para conferir veridicidade ao relato, Franco recorreu aos médicos e cirurgiões que a teriam examinado, para ressaltar que "nada era natural", nem a flexibilidade do corpo morto, o calor que o mesmo conservava e o cheiro agradável da roupa. Segundo os laudos médicos, Thomázia não teria apresentado os "olhos vidrados", como era de esperar no instante da morte; pelo contrário, seus olhos pareciam estar animados, seu sangue parecia correr ainda pelas veias e sua carne apresentava-se muito flexível. ${ }^{32}$

Inúmeros foram os "prodígios" a ela atribuídos após a morte, especialmente aqueles relacionados à cura de enfermidades, dores e moléstias, mas também favores e auxílios aos vivos. Para que as graças fossem alcançadas, muitos fiéis recorriam aos seus objetos pessoais - tomados como relíquias -, tais como o véu e/ou a capa com o qual costumava comungar, ao consumo de um copo de água oferecido à cova da "serva de Deus" ou, então, ao choro constante e às orações diante da sepultura.

Desejosa de se unir ao divino, "morta de amor" por Deus, Thomázia entregou "a alma ao seu Criador na segunda-feira depois da Dominga da Santíssima Trindade pelas cinco horas da manhã do dia 26 de maio de 1755" (Franco, 1757: 79). É plausível supor que a leitura da obra sobre a vida portentosa desta mulher, cuja conduta exemplar lhe havia assegurado os "frutos do céu", tenha servido de consolo a uma parcela da população lisboeta, para a qual o terremoto de novembro de 1755 foi uma manifestação da fúria divina. Pode-se, ainda, supor que a morte de Thomázia, ocorrida seis meses antes do cataclismo, tenha contribuído para reforçar ainda mais sua fama de santidade junto aos leitores da obra de Franco, pois sobre ela não teriam recaído os castigos aplicados aos pecadores lisboetas. 
Não se deve, por fim, desconhecer que este gênero de literatura alcançava indistintamente homens e mulheres, que, em busca de orientação religiosa ou lazer, devem ter lido - ou ouvido - o relato edificante que seu confessor, o padre dominicano João Franco, realizou - motivado pela milagrosa preservação dos documentos pessoais de Thomázia após o desastroso terremoto de 1755 - sobre a Vida portentosa de Dona Thomázia de Jesus. A vida desta mulher devota foi tomada por Franco como modelo de conduta virtuosa, sendo apenas uma entre as tantas outras que mereceram a atenção do clero regular ou secular, que a elas recorreram para exaltar as virtudes esperadas dos fieis católicos entre o século XVII e o XVIII.

\section{NotAs}

1 Agradecemos aos pareceristas de Estudos Históricos pelas pertinentes recomendações e apreciações críticas, as quais contribuíram significativamente para o aprimoramento do texto e para a qualificação de boa parte dos principais argumentos deste artigo.

2 BNP, Biblioteca Nacional de Portugal, FRANCO, João. Vida portentosa da serva de Deus D. Thomazia de Jesus, terceira professa da Venerável Ordem de S. Domingos, que habitou muitos anos no Convento de Salvador desta Cidade de Lisboa, onde faleceu no dia 26 de maio do ano de 1755, escrita pelo seu confessor o padre Fr. João Franco, da Sagrada Ordem dos Pregadores, Mestre em Santa Teologia, Consultor do S. Ofício, e Prior atual do Convento de S. Domingos de Lisboa, e dedicado ao sereníssimo senhor D. Pedro, infante de Portugal, por Caetano de Andrada Pinto, fidalgo da Casa de S. Majestade, e seu Guarda-roupa. Lisboa, na oficina de Miguel Manescal da Costa, impressor do Santo Ofício, 1757.

3 Sobre esta fonte já realizamos outras análises. Ver Fleck e Dillmann (2012, 2013).

4 Embora a fonte aqui analisada possa ser definida como uma biografia, e a descrição dos aspectos biográficos seja relevante para os propósitos deste artigo, não tivemos a pretensão de realizar um estudo baseado nos pressupostos teórico-metodológicos das biografias históricas, uma vez que não estamos interessados em biografar ou identificar a trajetória de vida de Thomázia. Apenas utilizamos a biografia para investigar os discursos de vida virtuosa e santificada.

5 É importante destacar que biografias com as de Dona Thomázia revelam "famas de santidade", e não a "santidade legitimada" que possibilitava o direito ao culto cristão-católico; do mesmo modo, as biografias parecem não questionar os decretos do papa Urbano VIII, como aquele promulgado em 1628, que, segundo o historiador José Pedro Paiva, "vedava a possibilidade de proceder à canonização ou beatificação de alguém antes de passarem 50 anos sobre a sua morte" (Disponível em http://www.snpcultura.org/novo_numero_lusitania_sacra_dedicado_santidade.html. Acesso em 28/11/2014). Ascender à santidade, portanto, desde 0 século XVII, na dinâmica católica, tornava-se prática controlada. Já a historiadora Célia Borges (2013: 2), apoiada em André Vauchez, nos informa que entre 1625 e 1634 o papa Urbano VIII controlava os pedidos de santificação através da exigência de que o "postulante à santidade (...) não tivesse sido objeto de culto".

6 A obra Imitação de Cristo, de Tomás de Kempis (1380-1471), já expressara muito bem essa busca pela interioridade proposta pela Devotio moderna e a orientação quanto à necessidade de purificar a alma através das orações, numa clara alusão ao pensamento de Santo Agostinho, que previa o cultivo do espaço interior, resguardado para a busca por Deus (Teixeira, 2011: 14). 
70 culto público era o critério básico para o reconhecimento da santidade. "À medida que a 'fé popular', e em particular a 'fé feminina', se purificavam de tendências heterodoxas através de uma multiplicidade de ações reformadoras, mais a elaboração de modos de santidade se tornava eficaz". Portanto, no período moderno, os modelos de santidade feminina e as virtudes excepcionais foram se tornando uma questão eclesiástica importante e reconhecidamente legítima para combater a "heresia" do protestantismo (Kessel, 1991: 196-197).

80 interesse social e "literário" a respeito da vida feminina atravessou séculos, tendo sido bastante comum a divulgação de biografias laudatórias de mulheres, como era o caso da obra Libro de las claras e virtuosas mujeres, escrito por D. Álvaro de Lima e publicado em 1446 com um catálogo de mulheres célebres, nobres e ilustres nas ciências, artes, militares e - destacamos - santas (Cubié, 2012: 16). Ainda sobre a educação e as atitudes femininas, especialmente aquelas que realçavam a humildade, a castidade, a obediência, a fidelidade, a submissão, a vergonha e a devoção, ver Fernandes (1995).

9 A historiadora Célia Borges (2012: 55) lembrou que desde a Idade Média, na Península Ibérica, diversas muIheres se destacaram por seus dons proféticos e místicos, com ênfase na mediação entre o humano e o divino.

10 Para o caso brasileiro, veja-se Leila Algranti (2004: 65) e Martins (2013), especialmente a respeito da obra do Arcebispo da Bahia, D. Sebastião Monteiro da Vida, Vida e morte da madre soror Victória da Encarnação (1661-1715).

11 É importante aqui destacar a diferenciação entre ambos. De acordo com o historiador Evergton Sales (2006: 114), "Diretor espiritual ou diretor de consciência é o padre que todo fiel tem o direito de escolher como guia de sua alma. Embora o diretor espiritual possa ser também confessor, é importante notar que se trata de duas funções distintas".

12 A autora divide a sua lista - na qual se encontra também Vida portentosa - entre biografias manuscritas e impressas. Citamos aqui algumas impressas: Breve relação da vida e morte prodigiosa da Madre Soror Maria Joana, Lisboa, Oficina de Manuel Coelho Amado, 1754; Vida de Soror Inês de Jesus, religiosa conversa no Convento da Anunciada desta cidade de Lisboa Ocidental [...], Lisboa, Nova Oficina de Maurício Vicente de Almeida, 1731; Desposórios do espírito celebrado entre o divino amante e sua amada esposa a venerável Madre Soror Mariana do Rosário, religiosa de véu branco no Convento do Salvador da cidade de Évora [...], por Fr. António de Almada, Eremita de Sto Agostinho, Lisboa, Manuel Lopes Ferreira, 1694; Fragmentos da Prodigiosa Vida da muito favorecida e amada Esposa de Jesus Cristo, a venerável Madre Mariana da Purificação, ordenados e expendidos por Fr. Caetano do Vencimento, Lisboa, António da Silva, 1747; Vida e obras da serva de Deus a Madre Mariana Josefa Joaquina de Jesus, religiosa carmelita descalça do Convento de Santa Teresa do lugar de Carnide, Lisboa, Régia Oficina Tipográfica, 1783; Vida da insigne mestra de espírito, a virtuosa Madre Maria Perpétua da Luz, religiosa carmelita calçada do convento da Esperança de Beja, por Fr. José Pereira de Santa Ana, cronista da mesma Ordem, Lisboa, Herdeiros de António Pedroso Galrão, 1742; Vida e milagres da venerável Madre Soror Francisca da Conceição, religiosa exemplaríssima no Mosteiro de Santa Clara da Vila de Trancoso, pelo Padre Simão Cardoso Pacheco, do hábito de S. Pedro, Lisboa, Oficina de António Pedroso Galrão, 1738; História da vida admirável (...) da venerável Madre Soror Brízida de Santo António, (...) abadessa do muito religioso Convento de Santa Brizida das Madres Inglesas, por Fr. Agostinho de Santa Maria, Lisboa, António Pedroso Galrão, 1701; História da vida e morte da Madre Soror Vitória da Encarnação, religiosa professa no Convento de Santa Clara do Desterro da cidade da Baía, pelo Arcebispo D. Sebastião Monteiro da Vide, Roma, Estamparia de João Francisco Chracas, 1720; Vida, virtudes e falecimento da venerável Madre Soror Joana Luísa do Carmelo, religiosa da Ordem Terceira de S. Francisco no Real Mosteiro de Santa Ana de Lisboa, fielmente escrita pelo seu Confessor. Fr. António do Sacramento, Lisboa, Oficina Herdeiros de António Pedroso Galrão, 1751.

13 A leitura de obras do gênero biográfico religioso foi prática comum nos ambientes conventuais, tendo contribuído sem dúvida para a reconstituição da "cultura religiosa do período", do "cotidiano conventual" 
e das "condições de vida das mulheres" (Algranti, 2004: 62). Esclarecemos que, embora a fonte possa ser reveladora destes aspectos, não constituiu objetivo deste artigo analisar a "cultura religiosa" e os aspectos do "cotidiano" conventual.

14 Isabel Braga (2010: 306-307) analisou justamente os comportamentos desviantes e bastante comuns nos conventos portugueses da arquidiocese de Braga, tais como "disputas nas eleições para abadessa, lutas pelas celas das religiosas que faleciam, cobrança de propinas às noviças quando professavam, violação da clausura, brigas provocadas por ciúmes, insultos, agressões físicas, posse de animais dentro do convento, realização de comédias e autos em ocasiões festivas, descuidos com os hábitos, uso de cosméticos e até práticas homossexuais".

15 Classificada por Paula Almeida Mendes (2013: 44) como vida de mulheres "ilustres em virtude", a obra Vida portentosa de João Franco aparece como a única, desta categoria, identificada pelas autoras como sendo de autoria de um membro da Ordem Terceira de São Domingos.

16 Sobre construção de "auto-imagem", ver Algranti (2004: 116). Ligia Bellini (2006: 88) destacou que muIheres residentes em conventos tinham "melhores possibilidades de deixar registros escritos de suas ideias e experiências". Como tais instituições estavam acostumadas com a escrita feminina, tendiam a preservar seus textos. Os escritos de Dona Thomázia foram preservados pelo Convento do Salvador, de Lisboa, mesmo depois do terremoto de 1755 , ano de sua morte.

17 Thomázia era uma mulher laica, no sentido de não eclesiástica. Elisja Kessel (1991: 198) usou o termo "semi-religiosa" para se referir a mulheres consagradas a Deus que não pertenciam ao clero, mas também não pertenciam ao mundo. Geralmente, mulheres como Thomázia, que, após a morte do marido, levavam uma vida semi-religiosa.

18 Leila Algranti (2004: 87) destacou que Lisboa, na primeira metade do século XVIII, possuía 18 conventos para mulheres. Era muito comum que no decorrer da vida muitas mulheres mudassem de ordem ou convento (Bellini, 2006: 94). Estes conventos converteram-se, ao longo do período moderno, em 'institutos de perfeição' moral (Kessel, 1991: 206).

190 historiador William de Souza Martins (2011) identificou na obra Armas da castidade, do padre Manoel Bernardes, a representação do matrimônio como um cativeiro, que desde o período medieval foi concebido como "um remédio para a concupiscência carnal", de modo que a inferioridade desse sacramento estaria ligada à "representação negativa das influências femininas".

20 A vida monástica apresentava-se às mulheres, segundo Ligia Bellini (2006: 87), como possibilidade de se libertar das funções do casamento e da "representação negativa da sua sexualidade", já que poderiam dedicar-se "a escrever textos religiosos" e "traduzir obras do latim para o vernáculo". Além disso, parece ter sido bastante comum o fato de mulheres de famílias nobres se dedicarem à vida conventual após terem ficado viúvas, inclusive com filhas presentes também nos conventos, de modo que estes se tornavam "uma espécie de substituto para o antigo núcleo familiar leigo" (Bellini, 2006: 94). 0 mesmo ocorreu com Thomázia e suas filhas. Em outras palavras, o convento apareceu para Thomázia como espaço de "retiro espiritual durante 0 casamento" e refúgio "definitivo na viuvez" (Braga, 2010: 306).

21 A virtude do silêncio parece ter sido muito valorizada pela parcela católica da sociedade portuguesa setecentista, pois, como destacaram Maria Lobo de Araújo e Carla Manuela Machado (2014: 04), "o silêncio, que constituía uma das maiores virtudes, nem sempre era guardado". As autoras citam o exemplo de Maria de Jesus que, no final do século XVII, na Misericórdia de Braga, "inquietava de tal forma as suas companheiras que não as deixava ouvir a 'palavra de Deus' na igreja, nem rezar no oratório do recolhimento, por estar junto dele a trabalhar 'na sua costura'". 0 próprio João Franco, autor da biografia de Thomázia, destacava em outra obra de sua autoria (Mestre da virtude, 1745), este "gênio" feminino não como regra, mas como potenciais caracte- 
rísticas das mulheres: elas seriam faladoras, coléricas, azedas. Por outro lado, Cubíe (2012 [1768]:17) arrolava qualidades e virtudes femininas, entre as quais estavam a constância, a capacidade de sigilo e a menor inclinação para a ira e a inveja. A virtude do silêncio, em especial do silêncio monástico, é muito anterior ao século XVIII e "acompanhava a mulher na vida de clausura", segundo Isabel Morujão (2011: 37). De acordo com esta pesquisadora, o silêncio era "eficaz para a oração, a intimidade com Deus e a caminhada na vida espiritual. Os manuais de perfeição religiosa, as regras monásticas, os tratados de moral, a sermonária e alguns escritores de um modo geral sublinhavam essa virtude no feminino, constituída pela escassez de palavras" (Morujão, 2011: 37).

22 Reflexões sobre a gula e a temperança estão presentes em Santo Agostinho, nas suas Confissões. Este Doutor da Igreja assinalava no final do século IV: "Sustento uma guerra quotidiana com jejuns, reduzindo o corpo à escravidão". E destacava que o motivo do comer e do beber residia na saúde, motivo pelo qual os alimentos deviam ser consumidos apenas como remédio. 0 prazer da alimentação juntava-se a esta necessidade como um companheiro perigoso, sendo necessário combater esta "delícia" (2011: 243-244).

$23 \mathrm{Na}$ análise das biografias de Jardim do Ceo, Bellini (2006: 104) notou as comuns "referências às disciplinas de ferro, aos cilícios de ferro pelo corpo, ao uso de roupas de tecido áspero e de uma tábua como cama". Entre os casos extremos destacou o de Isabel Maria da Conceição, que "rasgou duas vezes o peito com um canivete", e o de Maria Josefa de Jesus, que "cobria a pele com urtigas e se deitava no chão à porta do coro, para que as demais pisassem nela".

24 Este aspecto também foi realçado por Algranti (2004: 116) ao destacar a humildade da beata Jacinta, sendo o destaque dado à humildade uma "característica da literatura devocional". Jacinta "chamava-se de 'besta', 'ser indigno e incapaz'".

$25 \mathrm{Na}$ interpretação de Lígia Bellini (2006: 101), "é mais provável que os poderes eclesiásticos de fato compartilhassem a crença na veracidade dos fenômenos e os tivessem como expressões de santidade, conquanto se tratasse de uma santidade mais cotidiana, que não gerava preocupações relativas à prática de formas de heterodoxia ou, num outro extremo, à necessidade de reconhecimento oficial e canonização".

26 Outras acusações poderiam ser dirigidas ao Santo Ofício, como ocorreu com a religiosa Jacinta de São José em 1753, quando Dom Antônio do Desterro acusou-a de "falta de humildade, desobediência ao prelado e vaidade" (Algranti, 2004: 78). Já outras foram processadas pela Inquisição "por fingirem êxtases, visões e revelação" (Bellini, 2006: 103).

270 desempenho destas práticas solidárias no sentido de curar enfermos também foi verificado na biografia de Madre Vitória da Encarnação, quando o biógrafo (Arcebispo Monteiro da Vide) destacou a relação da beata com duas escravas doentes. William Martins (2013: 216) anotou: "Em razão das ameaças de contágio, as religiosas solicitaram que as duas fossem expulsas da clausura. Madre Vitória, discordando da iniciativa, respondeu-lhes: 'deixassem estar as negrinhas na sua Cela, que Ela as curaria'".

28 Ver exemplo em Bellini (2006: 90-91), que também buscou destacar indicações de posição social e financeira de mulheres enclausuradas.

290 terremoto de $1^{\circ}$ de novembro de 1755 destruiu casas, palácios, ruas, igrejas, conventos, tribunais, livrarias, entre outras construções de Lisboa. A estimativa do número de mortos ficou em torno de dez mil pessoas. Como o terremoto ocorreu no dia de todos os santos, um dia especialmente religioso para grande parte da população que rezava e acendia velas, os efeitos dos incêndios foram ainda maiores. 0 discurso religioso sobre as causas do terremoto apontaram argumentos de origem e intervenção divina, como uma punição de Deus e um efeito de sua ira diante dos vícios dos habitantes da cidade (Ferro, 2009: 31-43).

300 infante D. Pedro "era filho de D. João V e de D. Maria Ana de Áustria" e "casou com a rainha D. Maria I, sua sobrinha" (Santos, 2013: 169). 
31 Isabel Morujão (2013: 82-99) analisou práticas e hábitos de leitura, audição (oralidade) e escrita de livros entre religiosas eruditas que, nas bibliotecas dos conventos portugueses, se reuniam e partilhavam leituras, escritas e ideias intra e extraconventuais.

32 Em sentido semelhante, as narrativas biográficas da religiosa Jacinta, analisadas por Leila Algranti (2004: 119), destacam que seu corpo "'conservou a cor e o calor naturais' até baixar à sepultura", sendo, portanto, uma morte edificante e com "odor de santidade".

\section{REFERÊNCIAS BIBLIOGRÁFICAS}

AgOStINHO, Santo, Bispo de Hipona, 354-430. Confissões. Trad. J. Oliveira e A. Ambrósio de Pina. Petrópolis: Vozes, 2011.

ALGRANTI, Leila Mezan. Livros de devoção, atos de censura: ensaios de história do livro e da leitura na América Portuguesa (1750-1821). São Paulo: Hucitec, 2004.

ARAÚjO, Maria Marta Lobo de. Pobres, honradas e virtuosas: os dotes de D. Francisco e a Misericórdia de Ponte de Lima (1680-1850). Barcelos: Editora do Minho, 2000.

\& MACHADO, Carla Manuela Sousa. "Janeleiras" e "faladoras": o quotidiano das mulheres no recolhimento de Santo António de Braga (séculos XVII e XVIII), ANAIS DO XVI ENCONTRO REGIONAL DE HISTÓRIA DA ANPUH-RIO: Saberes e práticas científicas, 28 de julho a 1 de agosto de 2014, p. 1-9.

BELLINI, Lígia. "Penas, e glorias, pezar, e prazer": espiritualidade e vida monástica feminina em Portugal no Antiga Regime. In:___ \& SOUZA, Evergton Sales (orgs). Formas de crer. ensaios de história religiosa do mundo luso-afro-brasileiro, séculos XIV-XXI. Salvador: Ed. UFBA, 2006, p.81-105.

BORGES, Célia Maia. As beatas e os inquisidores: representação do diabo para os agentes do Santo Ofício. In: SIMÕES, Bárbara \& DAIBERT JR, Robert (org). Escrituras de Deus e do Diabo: ensaios de religião, história e literatura. Juiz de Fora: Ed. UFJF, 2012, p. 53-72.

. Os eremitas no Brasil-Colônia: Frei Pedro Palácios e a projeção de um modelo de santidade. XXVII SIMPÓSIO NACIONAL DE HISTÓRIA, ANPUH, Natal/RN, julho 2013, p. 1-11.

BRAGA, Isabel M. R. Mendes Drumond. Vaidades nos Conventos femininos ou das dificuldades em deixar a vida mundana (séculos XVII-XVIII), Revista de História da Sociedade e da Cultura, 10, tomo I, 2010, p. 305-322.

CERTEAU, Michel de. A invenção do cotidiano: 1. As artes de fazer. Petrópolis: Vozes, 1994.

CHARTIER, Roger. Do palco à página: publicar teatro e ler romances na época moderna, séculos XVI-XVIII. Rio de Janeiro: Casa da Palavra, 2002.

CUBÍE, Juan Bautista. Em defesa das mulheres das calúnias dos homens: com um catálogo das espanholas que mais se destacaram nas Ciências e nas Armas. Trad. Dafne Melo. São Paulo: Ed. Unesp, 2012 [1768].

DARNTON, Robert. Poesia e polícia: redes de comunicação na Paris do século XVIII. Trad. Rubens Figueiredo. São Paulo: Companhia das Letras, 2014.

FERNANDES, Maria de Lurdes Correia. Espelhos, cartas e guias: casamento e espiritualidade na Península Ibérica, 1450-1700. Porto: Instituto de Cultura Portuguesa, FLUP, 1995.

FERRO, Carolina Chaves. Terremoto em Lisboa, tremor na Bahia: um protesto contra o donativo para a reconstrução de Lisboa (1755-1757). Dissertação (mestrado em História), UFF, Niterói, 2009.

FLECK, Eliane Cristina Deckmann. "Moviome a escribir este libro, el deseo de reunir en un cuerpo, lo que no he podido hallar en libro alguno": reflexões sobre evidências de circulação e de apropriação de saberes e práticas científicas na obra de Materia Medica Missioneira de Pedro de Montenegro (1710). In: ALVIM, Márica 
Helena (org.). Conhecimento, cultura e circulação de ideias na América Colonial Luso-hispânica. Santo André: Universidade Federal do ABC, 2014, p. 21-50.

\& DILLMANN, Mauro. "A Vossa graça nos nossos sentimentos": a devoção à Virgem como garantia da salvação das almas em um manual de devoção do século XVIII. Revista Brasileira de História, v.32, n.63, jan.-jun. 2012, p.83-118.

\& __. Os sete pecados capitais e os processos de culpabilização em manuais de devoção do século XVIII, Topoi, Revista de História, v. 14, n. 27, 2013, p. 285-317.

FRANCO, João. Vida portentosa da serva de Deus D. Thomazia de Jesus, terceira professa da Venerável Ordem de S. Domingos. Lisboa, na oficina de Miguel Manescal da Costa, impressor do Santo Ofício, 1757.

JAPIASSU, Hilton \& MARCONDES, Danilo. Dicionário básico de filosofia. $4^{\mathrm{a}}$ ed. Rio de Janeiro: Jorge Zahar, 2006.

JULIA, Dominique. Leituras e Contra-Reforma. In: CHARTIER, Roger \& CAVALLO, Guglielmo. História da leitura no mundo ocidental. São Paulo: Ática, 1999, p. 79-116.

KESSEL, Elisja Schulte van. Virgens e mães entre o céu e a terra. As cristãs no início da Idade Moderna. In: História das Mulheres no Ocidente, do Renascimento à Idade Moderna v. 3. Porto: Afrontamento, 1991, p. 181-227.

MANGANARO, Patrizia. Alteridade, filosofia, mística: entre fenomenologia e epistemologia. In: Memorandum, 6, 3-24. Disponível em: http://www.fafich.ufmg.br/ memorandum/artigos06/manganaro01.htm. Acesso em: 2 jan. 2010

MARTINS, William de Souza. Representações femininas na obra do padre Manuel Bernardes (1644-1710), Lócus: Revista de História, Juiz de Fora, v.17, n.2, 2011, p. 35-55.

Um espelho possível de santidade na Bahia colonial: madre Vitória da Encarnação (1661-1715), Revista Brasileira de História, São Paulo, v. 33, n. 66, 2013, p. 209-227.

MORUJÃO, Isabel. Poesia e santidade: alguns contributos para uma percepção do conceito de santidade, a partir de duas biografias devotas de religiosas do séc. XVIII, Via Spiritus, n. 3, 1996, p. 235-261.

. Incidências de 'esperança mística' num solilóquio de sóror violante do céu 'para a agonia da morte', Os 'últimos fins' na cultura Ibérica (XV-XVIII), Revista Fac. Letras - Línguas e Literaturas, VIII, Porto, 1997, p. 205-235.

. Morrer ao pé da letra: relatos de morte na clausura feminina portuguesa, Via Spiritus, 15, 2008, p. 163-194.

Entre a voz e o silêncio: literatura e espiritualidade nos mosteiros femininos, Rever, ano 11, n. 1, jan. jun. 2011, p. 35-54.

Por trás da grade: poesia conventual feminina em Portugal (sécs. XVI-XVIII). Lisboa: Imprensa Nacional, Casa da Moeda, 2013.

SALES SOUZA, Evergton . Catolicismo ilustrado e feitiçaria. Resultados e paradoxos na senda da libertação das consciências. CEM Cultura, Espaço \& Memória, v. 3, 2012, p. 45-62.

SAMPAIO, Gabriela dos Reis (org.). Formas de crer: ensaios de história religiosa do mundo luso-afro-brasileiro, séculos XIV-XXI. Salvador: Edufba, 2006, p. 81-106.

SANTOS, Zulmira; MENDES, Paula Almeida; NEMÉSIO, Inês. Fontes para o estudo da santidade em Portugal na Época Moderna. Centro de Investigação Transdisciplinar Cultura, Espaço e Memória, Faculdade de Letras da Universidade do Porto, Portugal, 2013.

SILVA, Innocêncio. Dicionario bibliographico portuguez. Estudos de Innocencio Francisco da Silva aplicáveis a Portugal e ao Brasil. Lisboa: Imprensa Nacional, Tomo III, 1859.

TEIXEIRA, Faustino. Apresentação. In: KEMPIS, Tomás de. Imitação de Cristo: com reflexões e oração de São Francisco de Sales. $2^{\mathrm{a}}$ ed. Petrópolis: Vozes, 2011. 